\title{
Revitalising Small Business Growth Strategies: Exploring the Risk-Benefit of Strategic Management Approaches
}

\author{
Michael Nnamseh ${ }^{1} \&$ Sunday S. Akpan ${ }^{2}$ \\ ${ }^{1}$ Department of Business Management, University of Uyo, Nigeria \\ ${ }^{2}$ Department of Banking and Finance/Insurance, University of Uyo, Nigeria \\ Coorespondence: Michael Nnanseh, Department of Business Management, University of Uyo, P.M.B. 1017, Uyo \\ Akwa Ibom State, Nigeria. E-mail: mp.mike8@yahoo.com
}

Received: April 17, 2015

Accepted: May 15, 2015

Online Published: June 25, 2015

doi:10.5539/ibr.v8n7p87

URL: http://dx.doi.org/10.5539/ibr.v8n7p87

\begin{abstract}
The growth of small and medium scale business is today, one of the objectives of government due to the role these businesses has to play in the development process of an economy. It is thus not surprising the various government interventions through incentives and grants in this subsector, and the imperative for a search for better ways of achieving growth. This paper is premised on this background with the overall objective of examining the risk-benefits of strategic management approaches of revitalising the growth strategies of SMEs. From a survey design adopted, data were collected from a sample 167 SMEs operators in AkwaI bom State, Nigeria and analysis using frequency and correlation statistics. The result indicated that strategic management approaches such as the balance scorecard, SWOT analysis, Porters' Five Factor Forces, and PEST analysis all have the risk-benefits of positively influencing the growth strategies of SMEs such as product development, market development, market penetration and diversification but that most SMEs do not usually give adequate consideration of these approaches before selecting and implementing their strategies. The paper concluded that SMEs failures are due to their inadequate consideration of strategic management approaches in the choice of growth strategies and recommended that SMEs should adopt an integrative strategic analysis of the various strategic factors in their operational environment before selecting and implementing their growth strategies. This way, they would grow sustainably and profitably and contribute meaningfully to the growth and development of the economy
\end{abstract}

Keywords: strategic management, risk-benefits, SMEs growth, economic growth

\section{Introduction}

\subsection{Statement of Research Problem}

The SME sector is dynamic. There has been an increase in the rate atwhich new businesses start up over the last 30 years. Changes in the economy and technology, subcontracting by large firms, rising unemployment and government policies towards welfare and a desire to support the enterprise culture have led to the emergence os SMEs (Storey, 1994). While many new firms start up each year, survival is more difficult. The first 3 years of a business are the most critical, with up to $50 \%$ ceasing to trade during that time (Burns, 2001). For example, small firms in the UK are six times more likely to fail than their larger counterparts (Storey, 1994) and 80\% of US businesses fail before the third generation (Bianchi, 2002).

According to Analoui and Karami (2003), failure is often caused by SMEs looking inward and not focusing on customer and market requirements, limited management skills and the owner's belief that they can do it all. Poor financing, under-capitalization and poor product quality may also contribute to their demise (Bianchi, 2002; Storey, 1994). The dot.com boom and burst provide evidence of the ease with which firms can be set up, but also the speed at which they can fold. The main reasons for this are an over-reliance on a new technology (the Internet) combined with limited market and customer analysis of new business opportunities. This is corrolary to SMEs being shortsighted in their strategy

Studies have proved that SMEs record high mortality rate and failure in achieving set goals arising from their incapacitation in the implemetation of strategies (Nnamsh, 2009; Akpan, 2007; Lolean, 2009; Briggs, 2010). Particularly, the SBA (2012) distributed failure if SMEs as presented thus: 


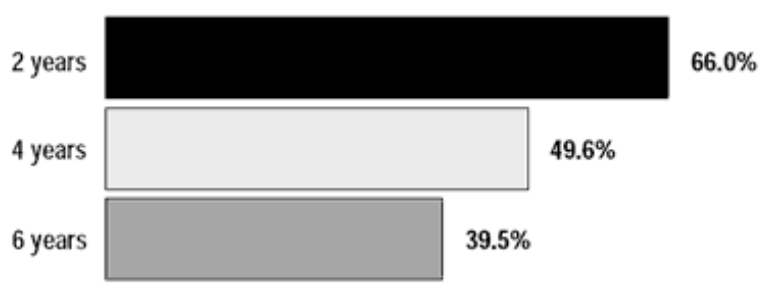

Figure 1. Failure rate of SMEs

Source: SBA (2012)Small Business by the Numbers.

As presented above, about $66 \%$ of SMEs failure occur within the first two years of operation, $49.6 \%$ failure occur within four years and 39.5\% failures occur within the first six years. The SBA (2012) further attributed these failure rates to lack of foresight by most SMEs operators. This lack of foresight is a symptome of absence of strategic management contents in the growth strategies of SMEs. Implicitly, SMEs often fall short of realising their growth objectives after the implementation of strategies. Although most SMEs failed to actualised their dream of growing their buinesses, it is doubtful if the application of strategic management could make any significant difference. Even if it would, it is still difficult to conlude that it would be tenable in Akwa Ibom State which is considered a civil service state with little or no entreprneurial mindset.

Again, it is also not known which SMEs growth strategy can best be influenced positively by the application of strategic management appraoch and also, which dimension of strategic management would best lead to improve SMEs growth strateigies to forestall the perenial early death of SMEs in the State. Furthermore, it is unknown to these researchers, whether SMEs have not been using strategic management appraoches and the degree to which the appraoches are used. Since business growth is one of the present day's coporate goal every business person want to achieve within a predetermined time period, and there is much ado about the potency of strategic management practices at engendering it, the researchers are of the view that a well selected, integrated and implemented strategic management strategy (ies) could improve SMEs growth sustainably and profitably in the face of the harsh and challenging operational environment.

The general objective of this study therefore, is to examine how small business growth strategies could be revitalised throught the application of strategic management approaches. Specific objectives are to:

I. Investigate the growth strategies of smes in an enterprise economy.

Ii. Ascertain the degree to which smes has used risk-benefits of swot to enhance their business growth strategies.

Iii. Investigate the degree to which smes have usded risk-benefits of pest to enhance their business growth strategies.

Iv. Examine the degreee to which smes have used risk-benefits of porter's five factor forces to enhance their business growth strategies

V. Investigate degee to which smes have applied the risk-benefits of balanced scorecard in enhancing their business growth strategies.

To achieve the above objectives, it was hypothesized genrally that the application of straregic management approaches has no risk benefits effect on SMEs growth strategies. Specific hypotheses were stated thus:

$\mathrm{Ho}_{1}$ There is no significant relationship between risk-benefits of SWOT and smes growth strategies.

$\mathrm{Ho}_{2}$ There is no significant relationship between risk-benefits of PEST and smes growth strategies.

$\mathrm{Ho}_{3}$ There is no significant relationship between risk-benefits of Porter's Five Factor Forces and smes growth strategies.

$\mathrm{Ho}_{4}$ There is no significant relationship risk-benefits of between Balanced Scorecard and smes growth strategies.

\subsection{The Importance of the Research Problem}

It is true that every small business wants to grow into a big one someday. This desire has generated several rhetoric questions among management experts as to how this lofty goal could be achieved. In the opinion of Chaudron (2014) many business mugguls often asked "What can we do to make our business survive and 
grow?". This perhaps has become the most asked but least answered question in business today. In what seems to be considered as response, Markson (2009) noted that in a bit to achieve growth, most organisations purposefully prioritised growth in revenue and profit as a target that must be achieved within a specified time period. This prioritisation makes business growth a strategic needs sought by many organisations to profitably and sustainably grow their enterprise. Sustainable growth which often carries with it the dividend of competitive advantage, economies of scale and leadership influence in the industry (Leon, 2011) has therefore become a topical issue of great concern by management of organisations. Consequenlty, business firms now see growth not as an option but, a necessity, yet they seems to lack the requisit strategy to achieve this growth. This therefore makes this investigation an important academic undertaking, especially now that SMEs growth has become a lofty business goal sought by both organisation's management and government in view of their role in national development.

In both developed and developing economies, small and medium scale enterprises (SMEs) are adjudged the main catalyst of economic development; especially considering their role in terms of employment generation, mobilisation of resources that would have otherwise been wasted, and the transformation of traditional industry among others (Onuoha, 2007). In nview of the fact the world is rapidly changing into something too hard to easily predict, with a hundred opportunities and pitfalls passing by every moment, there is therefore, a continous emphasy and call for more entrepreneurial venture creation and operation. For SMEs to continue in offering the contributions and survive in the long run, it must keep growing and be so encouraged. Consequently, several enablements through grants, incentives and soft loans have been provided to encourage venturesome vis-à-vis the development of SMEs from the grassroots globally. In search for ways and strategies toward the attainment of this new paradigm of business goal, businesses device several strategies one of which is business re-engineering process (BRP). As noted by Onuoha (2007), the BRP requires adequate consideration of the strategies that are both profitable and sustainable. In a seminal study by Nnamseh (2009), strategic management appraches are one of the BRP's method of driving growth in SMEs.

According to Nnamseh (2009), bsuinesses of all sizes can grow if they adopt strategic management approaches. The author explained further that most businesses die untimely due to what he called strategic shortsightedness which he defined as a situation where business refuses or does not look beyond the present realties into the future expectations in both directions. He however, submmitted that looking into the future of businesses require an adaptation and application of strategic management strategies or approaches to revitalise SMEs growth strategies and gauge the perenial risk of SMEs failure.

\subsection{Descritption of Relevant Scholarship}

Strategic management is the process and approach of specifying an organization's objectives, developing policies and plans to achieve and attain these objectives, and allocating resources so as to implement the policies and plans. In other words, strategic management can be seen as a combination of strategy formulation, implementation and evaluation (David, 2005). Strategic management theories stem mainly from the systems perspective, contingency approach and information technology approach. In light of this background, David (2005) and Mohd (2005), among others identified profit-maximizing and competition-based theory, the resource-based theory, the survival-based theory, the human resource based theory, the agency theory and the contingency theory as giving support to the proposition of strategic management approaches as growth enablers.

Therefore, in this paper, besides the systems perspective, contingency approach and the other main strategic management theories mentioned above, the resource-based theory or view (RBV) of the firm's competitive advantage in particular will be the underlying theoretical foundation applied and fundamental basis of the variables and their ensuing relationships that are being studied. This is because this paper will focus especially on the internal attributes (i.e. resources, capabilities and systems) of the organization towards attaining competitive advantage. Although there are also some minimal external dimension and elements being considered (i.e. interactions), these elements are mainly inherent within the organization. Hence, it justifies the adoption of the RBV as the main research tenet.

There are many strategies to choose from and good method that could be used for implementing a growth strategy. It is important to stress at this point that, it is not just choosing a strategy that matters most, but caution must be exercised to ensure that the most appropriate ones are selected based on the nature of the business and its operating environment. Some common growth strategiesin business include market development, product expansion, market penetration, diversification and acquisition among others.

The strategy of market development is often considered a more common growth strategy which involves expanding existing products into new and untapped markets. If a business does not find new markets for its 
products, it cannot increase sales or profit. Product development focuses on introducing new products into existing markets. Market penetration involves growing existing products in existing markets. Diversification is a situation where a small company will sell new products to new markets. This type of strategy could be risky if a company is not sufficiently funded (Major, 2011). All the same a small company will need to plan carefully when using this strategy. Meger and Acquisition may use this type of strategy to expand its product line and enter new markets. According to Markson (2009), an acquisition growth strategy may be risky but though not as risky as diversification strategy.

Empirically, the majority of firms do not grow because they lack strategic content in their chosen strategy. Many focus on survival, what Storey calls the trundlers. According to the author,

Trundlers may be in business for lifestyle advantages or they may have owners who want to control every aspect of the business. In many cases these lifestyle firms are in business to provide owners with an adequate income from an activity that they enjoy. Management activity is carried out in a routine way at an operational level to ensure that the day-to-day issues are addressed.

Impplicitely, the owners of these firms do not think about long-term business strategy (ie strategy with strategic management content). Change is only brought about when the business begins to fail, most likely because the market has, unknown to the owner, changed (Burns, 2001). These firms rarely use strategic management to provide them with knowledge and information about future state of the business or industry. Management activity is carried out in a routine way at an operational level to ensure that the day-to-day issues are addressed.

Strategic management involves a comprehensive organizational set of corporate, business and functional strategies for defining the company's objectives, vision and mission. Several authors (Arieu, 2007; Nag, Hambrick, \& Chen, 2007) have defined strategic management differenctly, but in all the definitions we can defined strategic management as a dynamic and complex process involving consideration of internal and external factors in the short and long term. Strategic management is concerned primarily with responses to external issues such as in understanding customers' needs and responding to competitive forces.

For SMes to grow, they must adopt or integrate whatever growth strategy used with strategic management stgrategies or approaches. It is noted that SMEs and many other business do not incorporate strategic management. On this. Burns (2001) regreted such practices, especially when SMEs set up monitoring systems at start-up and thereafter refuses to continuously invest in them. The author however advised that it is important to have good strategic management tools in place to monitor all aspects of the business. In view of the above, it appears that for SMEs to grow, it must maitained a strategic posture as illustrated in Figure 2 that follows:

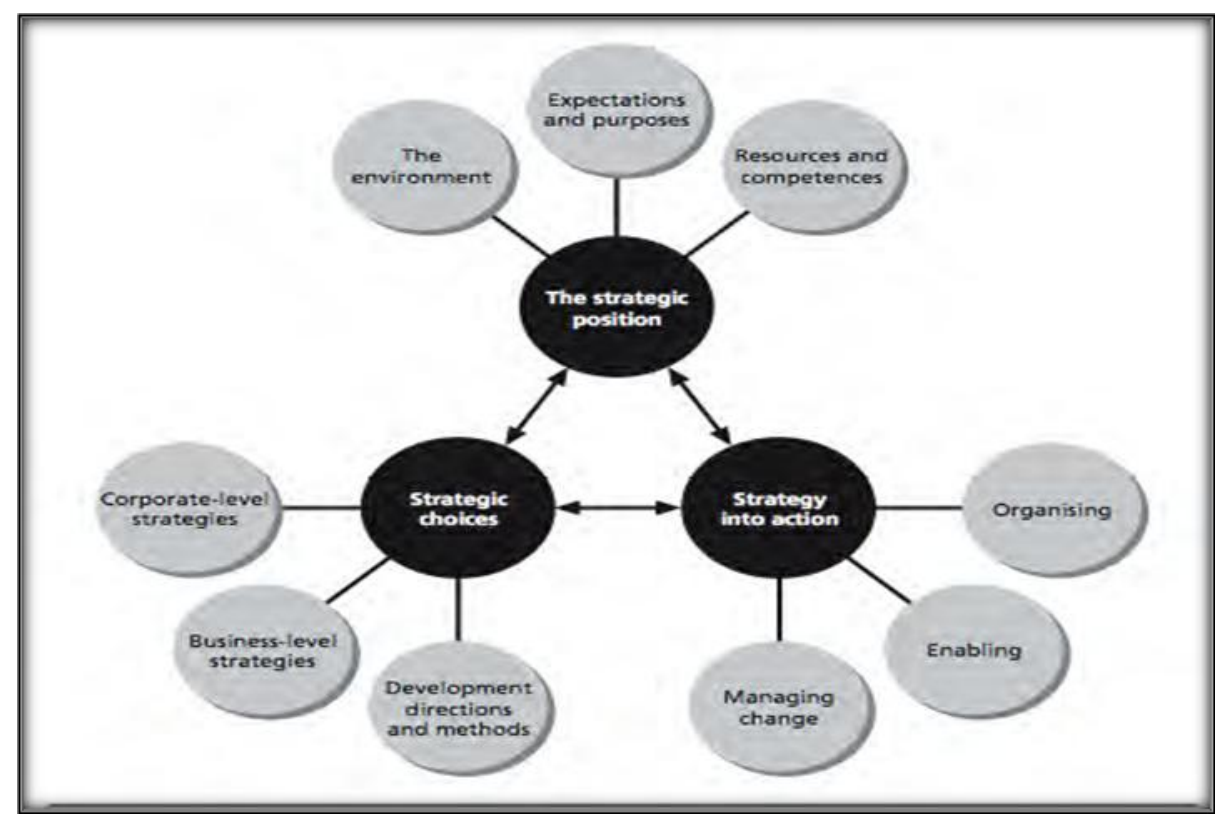

Figure 2. SMEs strategic posture for growth

Source: Researcher's Inference from the Internet. 
From the above, growth drunk SMEs must not only think of business growth but must be seen as being committed to achieving and sustaining the growth. According to Dahl (2013), business growth...is more than wishful thinking..., it is not an option-it is a necessity. To grow your business in any economy requires the right strategy in the right market at the right time. When a "match" is accomplished, high growth happens. Although there are allot of strategies to choose from, you want to select the growth strategy most appropriate for your business. Here are four key strategies for your consideration to help you gain traction in your marketplace and fast forward your growth: Diversification strategy, Market Development strategy, Product Development strategy, and Market Penetration strategy.

The position of these researchers is that, never choose or select any of the mentioned strategy until such strategy has a strategic management content. In other words, for sustainable growth to be achieved, strategic management approach must be adopted to choose or selected a particular strategy. These strategic management approaches include SWOT, PEST, the balance score card, porter's five factor forces.

SWOT stands for strengths and weaknesses, opportunities and threats. It is one of the most basic and widely-used strategic management approach which is often used to examines both internal elements (strengths and weaknesses) of the organizationand external elements (opportunities and threats).

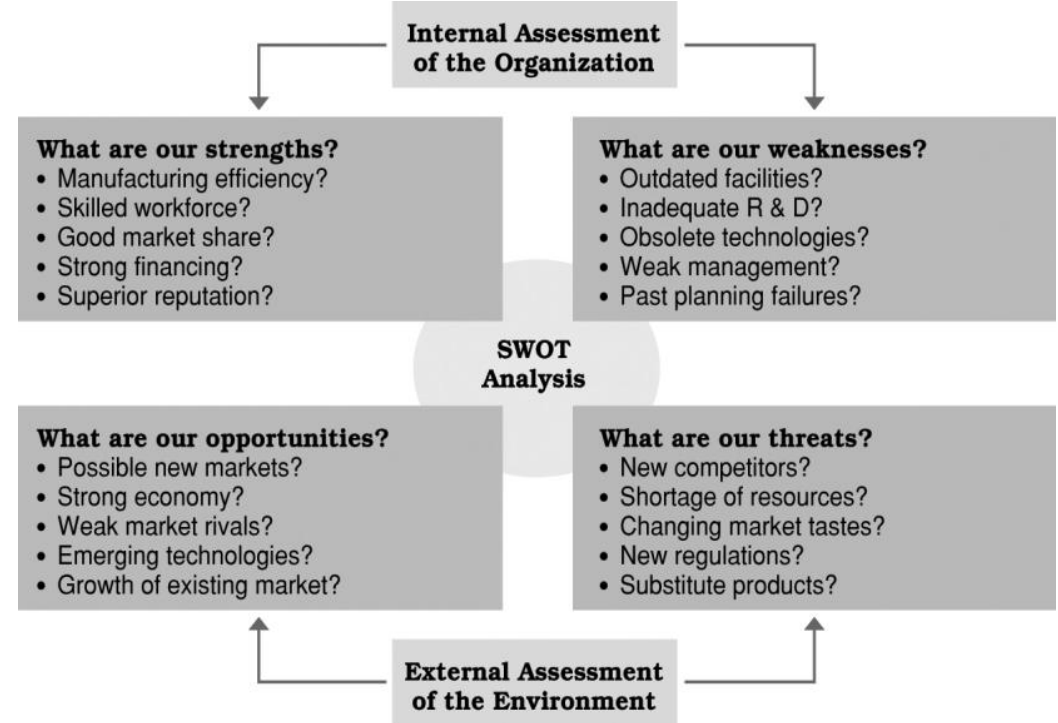

Figure 3. Specific SWOT concerns for SMEs growth

Source: Researcher's Inference from the Internet.

As illustrated in Figure 3, two factors: the strengths and opportunities are helpful while two factors are harmful to achieving the objective (in our SMEs growth) of the organization. In Figure 3, specific issues and questions that SMEs would have to be bogged with are highlighted. The Figure presents a clearer picture of the various composition of SWOT which will form the nucleus of discussion in this study.

PEST, as strategic management approach, stands for politics, economics or environment, social and technological factors. Nag, Hambrick and Chen (2007) said, "in addition to the industry factors that can affect a company's performance, there are also a number of outside factors that play a role in how successful businesses can be" and in order to determine how big a role those external factors play, many organizations conduct a PEST analysis. As indicated in Figure 3 below, a PEST analysis looks at how those external factors can affect a business's activities and performance, and it can be used in combination with other tools, like Porter's five forcesand aSWOT analysis, to determine an organization's overall outlook for success. To get the most out of a PEST analysis, businesses must understand what each of the four factors is analyzing as briefly highlighted in Figure 4 that follows. 


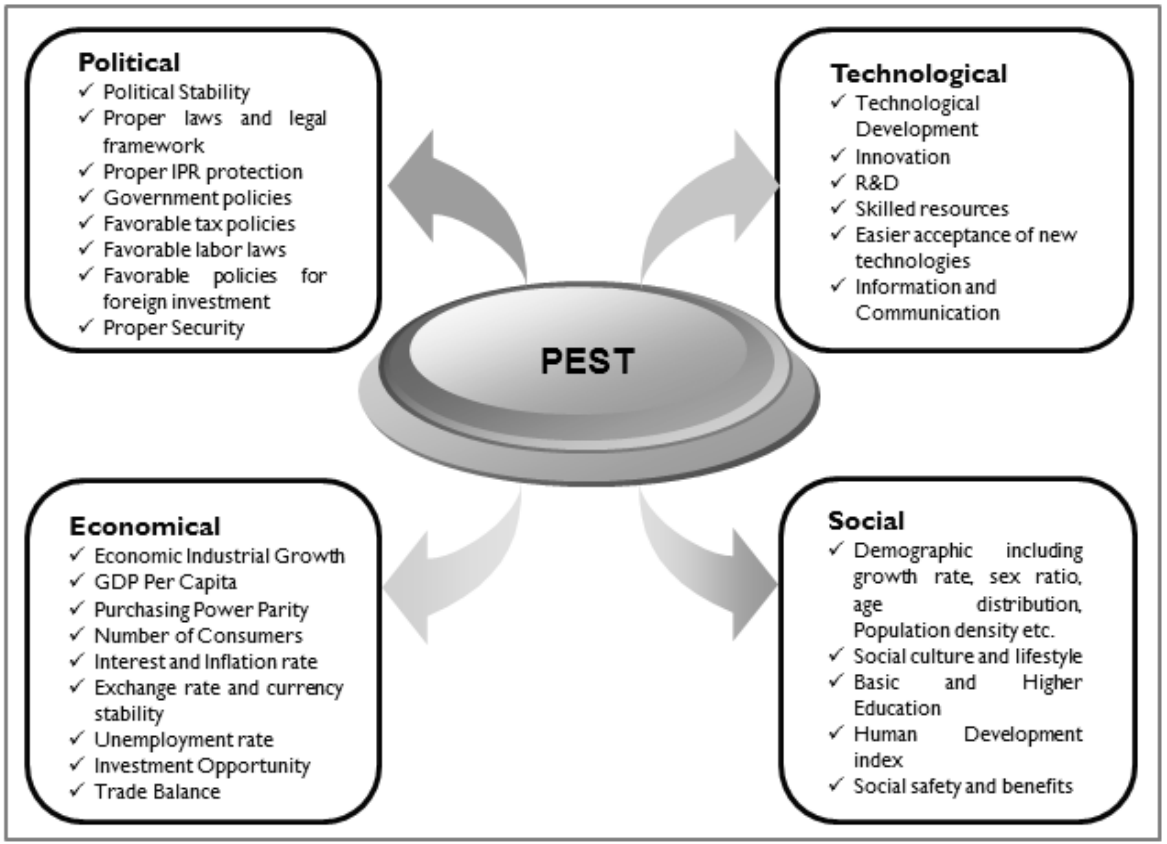

Figure 4. Components of PEST

Source: Researcher's Inference from the Internet.

As companies around the world transform themselves for competition that is based on information, their ability to exploit intangible assets has become far more decisive than their ability to invest in and manage physical assets. Several years ago, in recognition of this change, a concept called the balanced scorecard wasintroduced.

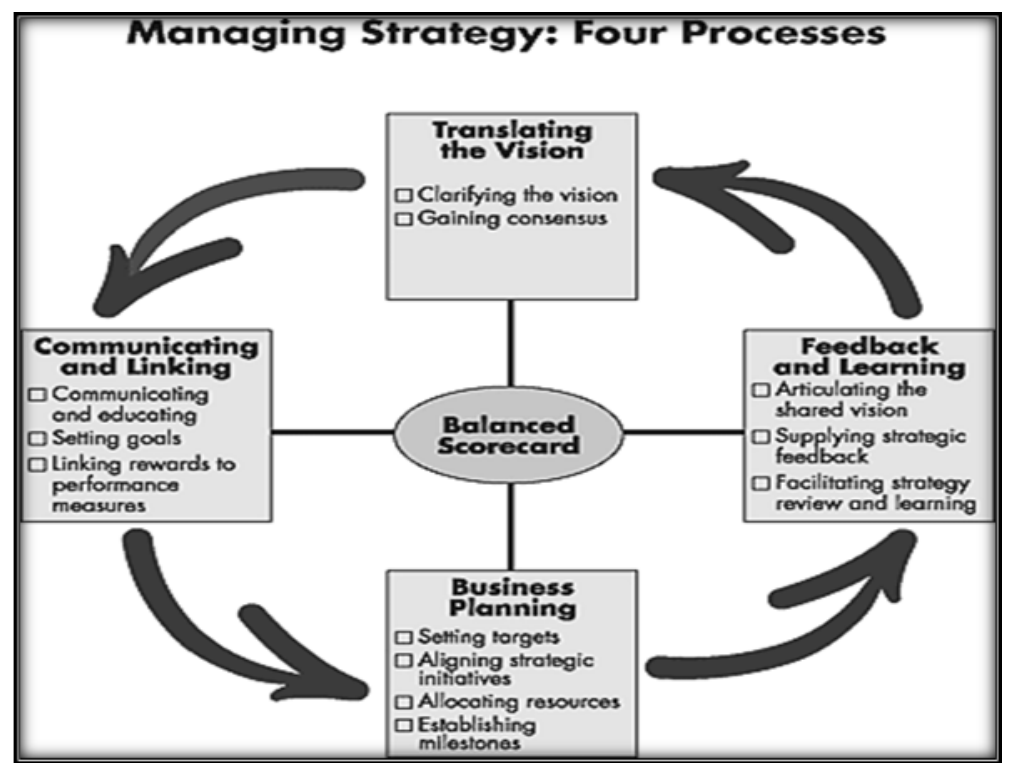

Figure 5. The balanced scorecard

Source: Researcher's Inference from the Internet.

As shown in Figure 5, the Balanced Scorecard attempts to measure the performance of an organization from the perspective of various stakeholders. The balanced scorecard is also valuable in strategic management because it helps to define and maintain competitive advantage. The scorecard lets them introduce four new management processes (translating the vision, communicating and linking, business planning, feedback and learning) that, separately and in combination, contribute to linking long-term strategic objectives with short-term actions. By 
this, strategic management approach, managers and operators of SMEs would come to term with the realities of the time being the fact that profitability is not a short term goal. Relevant empirical study on this was carried out by McCuddy (2007) who reported that of the more than 100 organizations that we have studied or with which we have worked implemented their first balanced scorecard with the intention of developing a new strategic management system.

Named after Michael E. Porter, (Porter, 1996), Porter Five Forces Analysis identifies and analyzes five competitive forces that shape every industry, and helps determine an industry's weaknesses and strengths. Five forces analysis helps organizations to understand the factors affecting profitability in a specific industry, and can help to make decisions relating to whether or not to enter a specific industry, to increase capacity in a specific industry and, to develop competitive strategies.

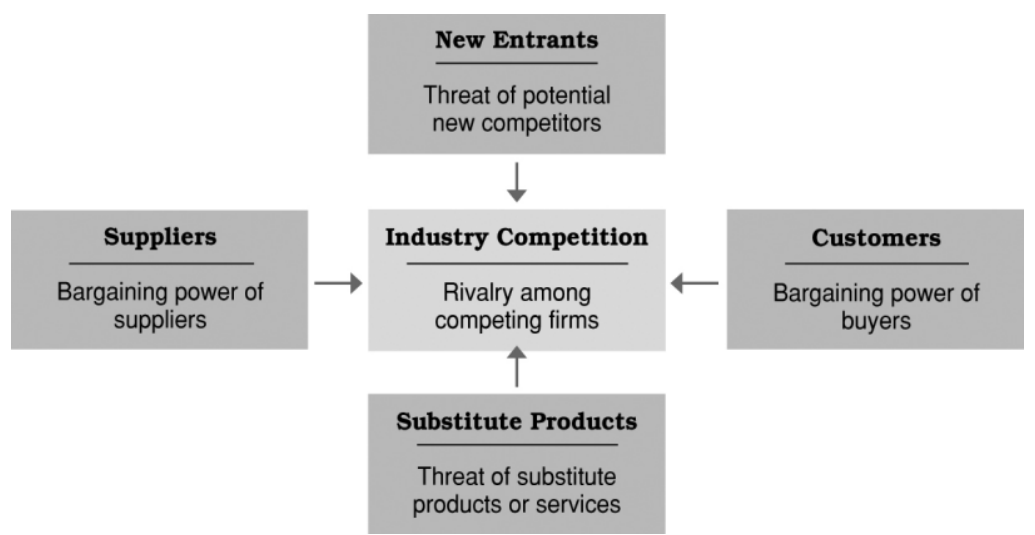

Figure 6. Description of the porter's five factor forces

Source: Researcher's Inference from the Internet.

In the context of SMEs growth, these parties in the distribution chain play major role by ensuring the supply of the product to buyers, failure of which will culminate into scarcity situation. When this strategic approach is applied, this relationship would be examined critically and possible avenues of inefficiency identified and provided for in the overall management decision concerning SMEs products in event of a soured relationship between the supplier and the buyer.

\section{Method}

In this study, the method adopted is an exploratory and descriptive research method. It is a method that calls for quantitative and analytical investigation of a named phenomenon. The adoption of this method is to allow the researchers to have adequate survey and freedom to report result independently and without interference in the research and test process. In other words, the method guarantees freedom from experimental manipulation and interventions by the researchers

\subsection{Sections of the Methodology}

The research method is divided into five sections namely research participants, sampling procedure, sample size, measurement and covariance, and research design.

\subsection{Research Participants}

The population used for this study comprise of 543 operators of SMEs selected from five urban locations in Akwa Ibom State. The locations and number of respondents used were Uyo/Itu (151), Eket/Ibeno (132), Oron (97). Idu Uruan (23), Etinan (31), Ikot Ekpene (109). These figures were however, obtained from the Registry of Bureau of Cooperative Society, Akwa Ibom State.

\subsection{Sampling Procedure}

The sampling procedure employed in this study is simple randomization. By the process, every element in the sampling frame was given a chance of being selected to participate in the research process. For equality of chance and reduction of bias, a questionnaire was given to every second person on the payroll of selected SMEs in the various locations. 


\subsubsection{Sample Size}

The sample used for this study was derived from the population using Taro Yamen's formula for sample size determination given thus: $\mathrm{n}=\mathrm{N} / 1+\mathrm{N}(\mathrm{e}) 2$. Given that $\mathrm{e}=5 \%, \mathrm{P}=543$; then, $\mathrm{n}$ is derived as follows: $\mathrm{n}=543 / 1+$ $543(0.05)^{2} ; 543 / 1+543(0.0025)=543 / 2.36=\mathbf{2 3 0}$.

Table 1. Sample distribution using Bowley's formula

\begin{tabular}{lcc}
\hline Sampled SMEs locations & Population & Sample \\
\hline Uyo/Itu & 151 & 64 \\
Eket/Ibeno & 132 & 56 \\
Oron & 97 & 41 \\
Idu-uruan & 23 & 10 \\
Etinan & 31 & 13 \\
IkotEkpene & 109 & 46 \\
Total & $\mathbf{5 4 3}$ & $\mathbf{2 3 0}$ \\
\hline
\end{tabular}

Source: Computed from the data provide.

To ensure that the sample drawn from the above sampling institutions are proportionate and scientific rather than arbitrary, Bowley's formula for sample distribution given thus: $\mathrm{n}=\mathrm{xh} / \mathrm{N}$. Where $\mathrm{n}=$ Distributed sample, $\mathrm{x}=$ Number of staff from each bank, $\mathrm{h}=$ Sample from population, $\mathrm{N}=$ Population of study. With the formula, the sample was distributed as shown in Table 1. Consequently, a total of 230 copies of questionnaire were developed and served to respondents, out of which a total of 223 copies were returned correctly and completely filled by respondents. The response rare being $96.96 \%$ very significant and was adjudged a fair representation of the sample and the population.

\subsubsection{Measurement and Scoring of Instrument}

The instrument was scored and rated on a five point Likert Scale thus: Strongly Agreed $(\mathrm{SA})=5$; Agreed $(\mathrm{A})=4$; Undecided $(\mathrm{UD})=3$; Disagree $(\mathrm{D})=2$; Strongly Disagree $(\mathrm{SD})=1$. The method of data technique used for this study was Pearson Product Moment correlation (PPMC) statistics denoted by ' $r$ ' and simple percentage frequency statistics. While PPMC was used to test the hypothesis, the simple percentage frequency statistics was used to treat the various research questions.

\subsubsection{Research Design}

In this study, a survey research design was employed in collecting data for analysis. By this design, the researcher was able to contact the respondents one on one for first-hand information on the subject matter.

\section{Results}

The investigation and analysis carried out in this study have shown that strategic management approach is a strategic measure to revitalising SMEs growth strategies for profitable and sustainable growth. For specificity, discussion are done in line with each objective. In other words, for purposes of clarity and avoidance of ambiguity in the findings of the report, each research objective is restated and findings made in that truce are mentioned and discussed accordingly.

\subsection{Statistics and Data Analysis}

Table 2. The growth strategies of SMEs in an enterprise economy

\begin{tabular}{lll}
\hline SMEs growth Strategies & Response & Percentage \\
\hline Diversification & 217 & 97.31 \\
Market Development & 109 & 48.88 \\
Product Development & 210 & 94.17 \\
Market Penetration & 201 & 90.13 \\
\hline
\end{tabular}

Source: Field survey data, 2015. 
From Table 2 above, it is obvoius that most, about $97.31 \%$ of the SMEs usually adopt a diversification strategy to pursue grwth, $48.88 \%$ adopt market development, $94.17 \%$ adopts product development while $90.13 \%$ adopt market penetration. In order of priority, many SMEs favours diversifaction and thereafter, product development followed by market penetration and finally market development as indicated in Fig. 6.

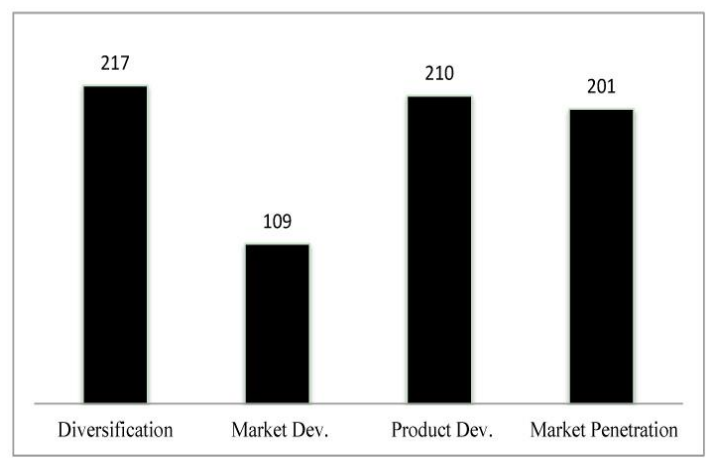

Figure 7. Pictorial presentation of SMEs growth strategies

Source: Computed from data on Table 2.

As indicated in Figure 7 above, the various growth strategies of SMEs were found to include diversification, product development, market penetration and, market development, in that order of usage.

Table 3. The degree to which SMEs have used SWOT to enhance their business growth strategies

\begin{tabular}{lcc}
\hline Research Statement & \multicolumn{2}{c}{$\begin{array}{c}\text { SMEs do spent considerable time in assessing their strenght and weaknesses and in finding profitable } \\
\text { opportunity and possible threats to their success before adopting their }\end{array}$} \\
\hline Options & Response & Percentage \\
Strongly Agrees & 49 & 21.97 \\
Agreed & 51 & 22.87 \\
Disagreed & 74 & 33.18 \\
Strongly Disagreed & 29 & 13.00 \\
Neither agree or disagree & 20 & 8.97 \\
Total & 223 & 100.00 \\
\hline
\end{tabular}

Source: Field survey data, 2015.

In Table 3, responses to SMEs consideration of SWOT in adopting growth strategy were presented. The highest response rate being $33.18 \%$ implies that majority of SMEs operators do not give reasonable consideration to SWOT analysis before adopting their growth strategy. To establish empirical significant of this theoretical responses, a test of hypothesis one which stated that "There is no significant relationship between risk benefit of swot and SMEs growth strategies" was carried out, and the result is presented in Table 4.

Table 4. Correlations result for risk benefit of SWOT and SMEs growth strategy

\begin{tabular}{llcc}
\hline & & SMEsGS & SWOT \\
\hline SMEsGS & Pearson Correlation & 1 & .601 \\
& Sig. (2-tailed) & & .013 \\
& $\mathrm{~N}$ & 5 & 5 \\
\hline \multirow{2}{*}{ SWOT } & Pearson Correlation & .601 & 1 \\
& Sig. (2-tailed) & .013 & \\
& $\mathrm{~N}$ & 5 & 5 \\
\hline
\end{tabular}

Source: SPSS Generated. 
The result indicates an r-value of .601 which means that SWOT analysis has about $60.1 \%$ contribution to the SMEs growth strategy. Since $60.1 \%>50 \%$ and p. $0.05>0.013$, the relationship or the contribution is considered positive and significant. Consequently, the null hypothesis which states that there is no significant relationship between SWOT and SMEs growth strategies is rejected in favor of the alternative hypothesis. This means that a carefully consideration of SWOT before choosing and implementing any strategy by SMEs will make about $60.1 \%$ improvement in the strategy adopted for growth by SMEs.

Table 5. The degree to which SMEs have used PEST to enhance their business growth strategies

\begin{tabular}{lcc}
\hline Research Statement & \multicolumn{2}{c}{$\begin{array}{l}\text { SMEs do spent considerable time in assessing political terren, economic factors, social issues } \\
\text { and changes in technology before adopting their growth strategy. }\end{array}$} \\
\hline Options & Response & Percentage \\
Strongly Agrees & 51 & 22.87 \\
Agreed & 54 & 24.22 \\
Disagreed & 66 & 29.60 \\
Strongly Disagreed & 22 & 9.87 \\
Neither agree or disagree & 30 & 13.45 \\
Total & $\mathbf{2 2 3}$ & $\mathbf{1 0 0 . 0 0}$ \\
\hline
\end{tabular}

Source: Field survey data, 2015.

Table 5 carries respondents' opinon on how much time SMEs spent on PEST analysis as a condition needed to chose their growth stategy. The highest response rate being $29.60 \%$ implies that majority of SMEs operators do not give reasonable consideration to PEST analysis before adopting tehir growth strategy. The corresponding hypothesis was that "there is no significant relationship between risk benefit ofPEST and SMEs growth strategies. The result of the test is contained on Table 6 below:

Table 6. Correlations result for risk benefit of PEST analysis and SMEs growth strategy

\begin{tabular}{llcc}
\hline & SMEsGS & PEST \\
\hline SMEsGS & Pearson Correlation & 1 & .646 \\
& Sig. (2-tailed) & & .029 \\
\multirow{4}{*}{ PEST } & $\mathrm{N}$ & 5 & 5 \\
& Pearson Correlation & .646 & 1 \\
& Sig. (2-tailed) & .029 & \\
& $\mathrm{~N}$ & 5 & 5 \\
\hline
\end{tabular}

Source: SPSS generated.

The result of the test of this hypothesis indicates an r-value of .646 which means that PEST analysis has about $64.6 \%$ contribution to the SMEs growth strategy. Since $64.6 \%>50 \%$ and p. $0.05>0.029$, the relationship or the contribution is considered positive and significant. Consequently, the null hypothesis which states that there is no significant relationship between PEST and SMEs growth strategies is rejected and the alternative hypothesis accepted. This means that a careful consideration of PEST before choosing and implementing any strategy by SMEs will make about $60.1 \%$ improvement in the strategy adopted for growth by SMEs. 
Table 7. The degree to which SMEs have used Porter's five factor forces to enhance their business growth strategies

\begin{tabular}{lcc}
\hline Research Statement & $\begin{array}{c}\text { SMEs do spent reasonable time in planning for new entrant to the industry, their supplires, customers, } \\
\text { substitutes products as well as compitition in the industry before adopting their growth strategy. }\end{array}$ \\
\hline Options & Response & Percentage \\
Strongly Agrees & 49 & 21.97 \\
Agreed & 55 & 24.66 \\
Disagreed & 75 & 33.63 \\
Strongly Disagreed & 21 & 9.42 \\
Neither agree or disagree & 23 & 10.31 \\
Total & $\mathbf{2 2 3}$ & $\mathbf{1 0 0 . 0 0}$ \\
\hline
\end{tabular}

Source: Field survey data, 2015.

In Table 7, the highest response rate was 33.63\%. This implies that majority of SMEs operators do not give reasonable consideration to analysing Porter's Five Factor Forces before adopting tehir growth strategy. The result (see Table 8) of the test of the hypothesis stating that "there is no significant relationship between Risk Benefit ofPorter's Five Factor Forces and SMEs growth strategies"shows an r-value of .597 which means that Porter's Five Factor Forces analysis has about 59.7\% contribution to the SMEs growth strategy.

Table 8. Correlations result for risk benefit of Porter's five factor forces and SMEs growth strategy

\begin{tabular}{llrr}
\hline \multicolumn{2}{c}{ SMEsGS } & PFFF \\
\hline \multirow{4}{*}{ SMEsGS } & Pearson Correlation & 1 & .597 \\
& Sig. (2-tailed) & & .028 \\
& $\mathrm{~N}$ & 5 & 5 \\
PFFF & Pearson Correlation & .597 & 1 \\
& Sig. (2-tailed) & .028 & 5 \\
\hline
\end{tabular}

Source: SPSS Generated.

Similarly, since $59.7 \%>50 \%$ and p. $0.05>0.028$, the relationship or the contribution is considered positive and significant. Consequently, the null hypothesis stating that there is no significant relationship between risk benefits of Porter's Five Factor Forces and SMEs growth strategies is rejected for alternative hypothesis. This means that a consideration of Porter's Five Factor Forces before choosing and implementing any strategy by SMEs will cause about $59.7 \%$ effectiveness of the strategy adopted for growth by SMEs.

Table 9. The degree to which SMEs have applied the balanced scorecard in enhancing their business growth strategies

\begin{tabular}{lcc}
\hline Research Statement & \multicolumn{2}{c}{$\begin{array}{c}\text { SMEs do give reasonableprior consideration to translating vision, cummunication and linkages, business } \\
\text { planning and feedback and learning and thereafter incorporate the experience into their growth strategy. }\end{array}$} \\
\hline Options & Response & Percentage \\
Strongly Agrees & 47 & 21.08 \\
Agreed & 50 & 22.42 \\
Disagreed & 81 & 36.32 \\
Strongly Disagreed & 21 & 9.42 \\
Neither agree or disagree & 24 & 10.76 \\
Total & $\mathbf{2 2 3}$ & $\mathbf{1 0 0 . 0 0}$ \\
\hline
\end{tabular}

Source: Field survey data, 2015. 
Finally, in Table 9, the highest response rate was $36.32 \%$. This implies that majority of SMEs operators do not give reasonable consideration to analysing the balanced scorecard before adopting their growth strategy. The result (see Table 10) of the corresponding hypothesis stating that "there is no significant relationship between the Balanced Scorecard and SMEs growth strategies" shows an r-value of .490 which means that Balanced Scorecard analysis has about $49.0 \%$ contribution to the SMEs growth strategy.

Table 10. Correlations result for balanced scorecard and SMEs growth

\begin{tabular}{llcc}
\hline & & SMEsGS & BS \\
\hline SMEsGS & Pearson Correlation & 1 & .490 \\
& Sig. (2-tailed) & & .402 \\
& $\mathrm{~N}$ & 5 & 5 \\
\multirow{3}{*}{ BS } & Pearson Correlation & .490 & 1 \\
& Sig. (2-tailed) & .402 & \\
& $\mathrm{~N}$ & 5 & 5 \\
\hline
\end{tabular}

Source: SPSS Generated.

Since $49.0 \%<50 \%$ and p. $0.05<0.402$, the relationship or the contribution is considered positive but insignificant. Consequently, the null hypothesis which state that "there is no significant relationship between the Balanced Scorecard and SMEs growth strategies is retained while the alternative hypothesis is rejected. This means that a careful consideration of Balanced Scorecard analysis before choosing and implementing any strategy by SMEs will make about $49 \%$ improvement in the strategy adopted for growth by SMEs.

\section{Discussions}

This finding on SMEs growth strtegy is very important as it has highlighted flaws often committed by SMEs in choosing and implementing growth strategies. The first flaw is inappropriate strategy selection. It is wrong to diversify when the market have not yet been identified or chances in the current market not found for penetration. Perhaps this may account for the reason why SMEs are considered to have a short life. You can only diversify into areas that have market to support you business. This finding is in tandem with past literature of Dahl (2014) who theoretcally suggested that SMEs that want to grow must take time to understand the market. This statement implies that market development must be the number one strategy that SMEs should strive to employ before thinking of any other strategy. However, the current practie of SMEs in terms of strategy selection and implementation lack strategic focus and can thus be adjudged as not having any strategic management content. Strategic selection and implementation is strategic is adopting market development before product development or diversification.

Finding on SWOT and SMEs growth strategy shows that SMEs do not consider the analysis of their strength and weaknesses in line with the opportunities and threats they face before selecting and implementing the strategies. This finding support the assertion of notable scholars such as David (2005) and Mohd, Khairuddin Hashim (2005) who found in their respective studies that most if not all SMEs often times than not, rush into business they hardly take time out to assess the business's tasks and potentials inward, and this most certainly account for the quick start-quick die status. Going by what the above expert said, it can be inferred that the inward assessment referred to here is the internal analysis of the strength as well as the weaknesses inherent in SMEs with a view to adjusting themselves and choosing the right strategy that would enable the business to stand and survive for a reasonable time period. Burns (2001) also made comment that this finding confirmed empirically as being true. According to the author, "SMEs are like trees without root in the "neighbouring ground"'. If we my understand this author from further explanations of the "neighbouring ground", it will mean that SMEs do not look outside of itself into the likelihood of external factors that are capable of marring the sustainability and survival. By this, SMEs can be said to not considering the threats and opportunities in the external environments before embarking on business exploit. This being so means that SMEs do not still consider SWOT analysis in their growth strategies.

It is unimaginable to found that SMEs do select their growth strategy without recurrence to the analysis of the political, economic, social and technological environment within which the business operate. This is because 
hardly would one talk about business without the mentioning of enabling environment and cost especially the influence of technology. Often time government is blamed for business failures due to what many considered as unfavourable policies. Should any business venture without taking into cognizance the role of government in an economy which, of course, is basically about policy formulation and implementation, such business will not survive longer and it would considered as not being strategic.

Again, the business world today is driven by technology. For SMEs seeking sustainable growth, it must critically analyse the technological environment with a view to ascertaining the emerging developments that will require their adaptation and adjustment or total compliance with the dictates of such development. Empirical finding from IDC (2005) support the finding of this study that SMEs do not usually consider technology - a cardinal element in PEST analysis before selecting and implementing their growth strategies. IDC (2005) statistics shows that SMEs usage rate of technology is growing at an insignificant rate globally as shown thus:

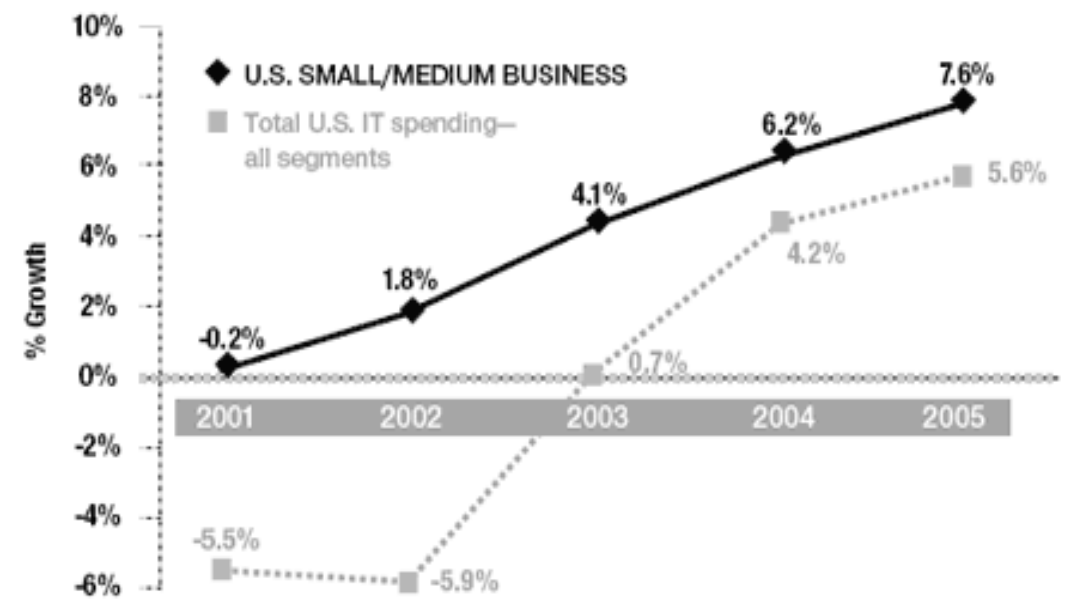

Figure 8. Growth trend of SMEs technology usage rate

Source: IDC SMB research and IDC Black Book, 2005.

The implication of the above is that SMEs get involve in ICT but at a level that is not capable of sustaining their growth. Perhaps the involvement may be made possible by chance and not a consciously planned and well examined attempt to particularly identify and analyse the risks and potentials a given technology has for the growth of SMEs.

The finding made concerning SMEs consideration of Porter's Five Factor Forces before selecting their growth strategy is startling. These forces were identified as threat of new entrant, suppliers, customers, substitutes products as well as competition were said to receive partial consideration with no concerted effort toward conscientious analysis. SMEs were said to look at competition as existent but not rife and often think of their suppliers suffering some sort of delay but not unavailable. When asked of any substitute product, every SME will say that their product is the first of its kind and that there is no substitute and that customers are already asking for their product. This position often exposed SMEs to relative risk analysis inherent in the forces. In a study carried out by Ayanda (2003), similar findings were made concerning SMEs disposition to these forces. According to the authors, SMEs knows their risk of early death due to their oversimplification of the market and other operatives and has taken steps to redress the situation. Explaining further, the authors mentioned that SMEs assume a monopolistic presence even when they are not in the market that is very fragile. This is just to try and scare new entrants and is very strategic as this makes them defensive.

Again, SMEs consider their suppliers as independent of them and know that they (SMEs) depend on the suppliers. Moreover, Ayanda (2003) made mention of the fact that SMEs considers their customers as not being hasty for their product while often very hasty to take advantage of the identified opportunity in the consumer market. All of these point to the fact that SMEs do take into consideration the five forces before selecting their growth strategy and this perhaps account for the relative long surviving rate of SMEs in most countries. In the US, the rate is given as $49.6 \%$ for four years and above and $39.5 \%$ for six years and above, (SBA, 2002).

The balanced scorecard is another strategic management appraoch that SMEs do not give adequate thought of 
before selecting and implementing their growth strategy. This finding is in tandem with Manyanhaire, Rwafa1 and Mutangadura (2011) who found that SMEs appraoch to strategic management is very thin such that the line distinguishing strategic management and tactical management tenates are shalow. This means that SMEs in selecting growth strategies think of immediate gains to be derived from selecting and implementing a growth strategy rather than think of what the strategy would bring to the organisation in the near future.

Moreover, Manyanhaire, Rwafa and Mutangadura (2011) said that most SMEs lack vission and are often short-sighted as they remain apt to shadow opportunities. Not having the vission make it impossible to think of translating it. In their further explanation, SMEs, with their advantage of being closer to customers than the large companies, do not take time to collect and analyse feedback from tehir customers. This again is not strategic as the continuos change in consumer demographics would marr SMEs chances of success if they do not consiously collect and analys feedback from their customers which finding will help them adjust and adopt to the emerging realities of the time.

\section{Conclusion and Recommendations}

In this study, we have argued that strategic management approaches can help SMEs to grow their business sustainably and profitably. Based on the extensive literature reviewed and analysis done, it is concluded based particularly on the findings of this study that SMEs do not consider strategic management strategies while selecting and implementing their growth strategies. It is genrally recommended that SMEs should adopt an integrative strategic analysis of the various strategic factors in their internal and exrternal operational environment before selecting and implementing their growth strategies. Specific recommendations are as follows

i. SMEs should analysis of their strength and weaknesses in line with the opportunities and threats they face before selecting and implementing the strategies.

ii. SMEs should always strive to analysis of the political, economic, social and technological factors within which the business operate. This way they will be able to adapt the organisational praftice to the emerging trends and realities.

iii. All SMEs devote reasonal level of time to the analysis of the threat of new entrant, supplires, customers, substitutes products as well as compitition before selecting and implementing their strategies.

iv. SMEs should give attention to precepts of thebalanced scorecard before selecting and implementing their growth strategy.

The zeal to grow SMEs in Nigeria has grown and the drive is on course. The various provisions and policy directives, have not considered the strategic management as being capable of driving sustainability and profitability in SMEs partly due to lack of empirically proven evidence. This study has therefore, makes such proof available for policy makers to recognize the role of strategic management in SMEs growth in any society. Also, the study has contributed to the stock of empirical literature on particularly strategic management and by extension SMEEs management.

\section{References}

Akpan, I. (2007). Fundamentals of finance. Modern Business Press Ltd., Uyo.

Analoui, \& Karami. (2003). Strategic management in small and medium enterprises. London, UK: Thomson Learning.

Arieu, O. (2007). Business strategy. Retrieved from http://www.sayeconomy.com

Ayanda, A. M. (2003). Enhancing organisational performance through strategic management: Conceptual and theoretical approach (Unpublished paper).

Bianchi, C. (2002). Introducing SD modelling into planning and control systems to manage SMEs' growth: a learning-oriented perspective. Systems Dynamics Review, 18(3), 315-338. http://dx.doi.org/10.1002/sdr.258

Burns, P. (2001). Entrepreneurship and small business. Palgrave, Hampshire, UK.

Carrington, M. (2013). Reframing the ethical consumption 'gap'. Conference Papers.

Chaudron, D. (2014). Begin at the beginning in organizational change. Retrieved from https://www.organizedchange.com

David, F. R. (2005). Strategic management: Concepts and cases (10th ed.). Prentice Hall, Pearson Education International.

Hay, M., \& Kamshad, K. (1994). Small firm growth: Intentions, implementation and impediments. Business 
Strategy Review, 5(3), 49-68. http://dx.doi.org/10.1111/j.1467-8616.1994.tb00166.x

IDC. (2005). Site development in U.S. small businesses. Retrieved June, 2004 from http://www.entrepreneur.com

Manyanhaire, I. O., Rwafa, R., \& Mutangadura, J. (2011). A theoretical overview of the growth centre strategy: Perspectives for reengineering the concept in Zimbabwe. Journal of Sustainable Development in Africa, 13(4), 1-13.

Mohd, K. H. (2005). Strategic management. Singapore: Thomson Learning.

Nag, R., Hambrick, D. C., \& Chen, M. J. (2007). What is strategic management, really? Inductive derivation of a consensus definition of the field. Strategic Management Journal, 28(9), 935-955. http://dx.doi.org/10.1002/smj.615

Onuoha, B. C. (2008). A critical analysis of impediment to entrepreneurship development of Nigeria. African Journal of Entrepreneurship, 1(1).

Penrose, E. T. (1959). The theory of the growth of the firm. New York: Wiley.

Porter, M. E. (1996). What is strategy? Harvard Business Review, November-December (1996).

SBA. (2004). Small business economic indicators for 2003.

\section{Copyrights}

Copyright for this article is retained by the author(s), with first publication rights granted to the journal.

This is an open-access article distributed under the terms and conditions of the Creative Commons Attribution license (http://creativecommons.org/licenses/by/3.0/). 